\title{
Prevalence of Premenstrual Syndrome Among University Students: Associated Factors and Comfort Level
}

\section{Üniversite Öğrencilerinde Premenstrüel Sendrom Prevelansı, ilişkili Faktörler ve Konfor Düzeyi}

\section{(D) Dilek YILDIRIM GÜRKAN1', iD Naile BİLGILI²}

${ }^{1}$ Yozgat Bozok University Vocational School of Health Services, Health Care Services, Yozgat, Turkey

${ }^{2}$ Gazi University, Public Health Nursing, Ankara, Turkey

\begin{abstract}
Objective: Premenstrual syndrome (PMS) is a combination of behavioral, somatic, emotional, and cognitive symptoms that are very common in women during reproductive age. The worldwide prevalence of PMS varies between $12 \%$ and $98 \%$. Thus, this study aimed to determine the prevalence of PMS and its associated factors and comfort level in a group of university students who stay in a dormitory.
\end{abstract}

Methods: This cross-sectional study was conducted in Yozgat Sürmeli Girls' Dormitory, which is located within Yozgat Bozok University Erdoğan Akdağcampus. A total of 1162 students are staying in the dormitory, and the study was completed with 935 students who stayed in the dormitory and volunteered to participate in the study without sample selection. The study collected data using the Participant Information Form that consist of 30 questions prepared by the researchers, the premenstrual syndrome scale (PMSS), and the general comfort scale (GCS). Percentage, mean, chi-square, t-test, correlation, and logistic regression analysis were used for data evaluation.

Results: The mean age of the students was $20.81 \pm 1.487$ years. The total score of the PMS scale was $115.21 \pm 41.615$. On the scale, the highest score is $20.203 \pm 7.493$ from the depressive affection dimension and the lowest score is $7.854 \pm 3.771$ from the sleep change dimension. PMS was found in $34.2 \%$ of students. The total GCS score of the students was $2.43 \pm 0.35$, and scores obtained from the sub-dimensions and GCS levels were lower in students with PMS. A weak and negative relationship was found between

\section{ÖZ}

Amaç: Premenstrüel sendrom (PMS), üreme çağındaki kadınlarda çok sık görülen davranışsal, somatik, duygusal ve bilişsel semptomların bir kombinasyonudur. Dünya çapında PMS prevalansı \%12 ile \%98 arasında değişmektedir. : Bu çalışmada, yurtta kalan bir grup üniversite öğrencisinde premenstrüel sendrom (PMS) prevelansı, ilişkili faktörler ve konfor düzeyinin belirlenmesi amaçlanmıştır.

Yöntemler: Kesitsel tipteki bu çalışma, Yozgat Bozok Üniversitesi Erdoğan Akdağ Kampüsü içerisinde yer alan, Yozgat Sürmeli Kız Öğrenci Yurdu’nda yapılmıştır. Yurtta 1.162 öğrenci kalmakta olup, örneklem seçimine gidilmeksizin yurtta kalan, çalışmaya katılmaya gönüllü olan öğrencilerin tamamının araştırmaya alınması planlanarak 935 öğrenci ile çalışma tamamlanmıştır. Araştırmada veriler; araştırmacılar tarafından hazırlanan 30 sorudan oluşan katılımcı bilgi formu, premenstrüel sendrom ölçeği (PMSÖ) ve genel konfor ölçeği (GKÖ) kullanılarak toplanmıştır. Verilerin değerlendirilmesinde yüzdelik, ortalama, ki-kare, t-testi, korelasyon ve logistik regresyon analizi kullanılmıştır.

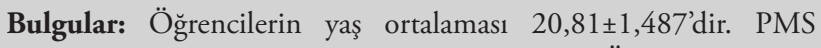
ölçeğinin toplam puanı $115,21 \pm 41,615$ 'tir. Ölçekte depresif duygulanım boyutundan en yüksek puan 20.203 \pm 7.493 ,

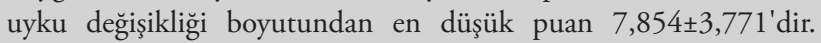
Öğrencilerin \%34,2'inde PMS saptandı. Öğrencilerin toplam GKÖ

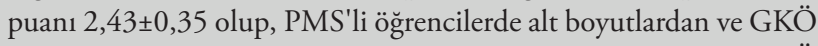
düzeylerinden elde edilen puanlar daha düşüktür. PMSS ve GKÖ arasında zayıf ve negatif bir ilişki bulundu. On üç yaş ve öncesinde

Address for Correspondence: Dilek YILDIRIM GÜRKAN, Yozgat Bozok University Vocational School of Health Services, Health Care Services, Yozgat, Turkey

E-mail: dilek.yildirim@yobu.edu.tr ORCID ID: orcid.org/0000-0001-8967-7939 
the PMSS and the GCS. The risk of PMS increased by 1.366 times $(\mathrm{p}=0.036)$ in students with menarche at the age of 13 years and younger, whereas, in students with chronic diseases, it was 2.512 times higher $(\mathrm{p}=0.001)$. The use of salt without tasting the food and daily coffee consumption increased the risk of PMS by 1.626 times $(\mathrm{p}=0.004)$ and 1.882 times $(\mathrm{p}=0.000)$, respectively. The risk of PMS was 2.026 times $(\mathrm{p}=0.000)$ higher in students with dysmenorrhea, whereas 1.614 times higher in students who used any method to cope with dysmenorrhea $(\mathrm{p}=0.004)$.

Conclusion: PMS is an important problem among women. A weak and negative relationship was found between PMS and comfort level. Considering the results of this study, menarche before the age of 13 , the presence of chronic disease, dysmenorrhea, excessive salt use, and coffee consumption increases the risk of PMS. Many factors lead to the occurrence of PMS. Interventional studies are necessary to reduce the risk factors for PMS that significantly affect the women's health or its risk factors.

Keywords: Premenstrual syndrome, prevalence, comfort level menarş olan öğrencilerde PMS görülme riski 1,366 kat artarken $(\mathrm{p}=0,036)$, kronik bir hastalığa sahip olan öğrencilerde PMS görülme riski 2,512 kat daha fazladır $(\mathrm{p}=0,001)$. Yemeğin tadına bakmadan tuz kullanımı PMS riskini 1.626 kat ( $\mathrm{p}=0,004)$, günlük kahve tüketme alışkanlığı 1,882 kat artırmaktadır $(\mathrm{p}=0,000)$. Dismenore yaşayan öğrencilerde PMS görülme riski, 2,026 kat $(p=0,000)$, dismenore ile baş etmek için herhangi bir yöntem kullanan öğrencilerde 1,614 kat daha fazladır ( $\mathrm{p}=0,004)$.

Sonuç: PMS kadınlar arasında önemli bir sorundur. PMS ile konfor düzeyinin negatif yönde, zayıf bir ilişkisi olduğu bulunmuştur. Bu çalışmanın sonuçları dikkate alındığında; 13 yaşından önce menarş olma, kronik hastalık varlığı, dismenore, fazla tuz kullanımı, kahve tüketimi PMS görülme riskini artırmaktadır. Birçok faktör PMS'nin ortaya çıkmasına neden olur. Kadın sağlığını önemli ölçüde etkileyen PMS risk faktörlerini veya risk faktörlerini azaltmak için girişimsel çalışmalara ihtiyaç vardır

Anahtar Sözcükler: Premenstrüel sendrom, prevelans, konfor düzeyi

\section{Introduction}

Premenstrual syndrome (PMS) is a combination of behavioral, somatic, emotional, and cognitive symptoms that occur during the luteal phase of the menstrual cycle, which is quite common among women during reproductive life, and rapidly improve with the onset of menstruation (1). More than 200 symptoms occur during the first 7-10 days of menstruation. The most frequent symptoms are headache, fatigue, bloating, back pain, breast tenderness, appetite changes, fatigue, anxiety, nervousness, impaired interpersonal communication, and depression (2). Determining the true prevalence of PMS with so many symptoms is difficult (3). Studies revealed different results in the prevalence of PMS depending on the diagnostic criteria and methodology (4). The systematic review and meta-analysis study that was conducted by Direkvand-Moghadam et al. (5) revealed that the prevalence of PMS varied between $12 \%$ and $98 \%$. The examination of countries in this study reported that the lowest prevalence was in France (12\%) and the highest prevalence was in Iran (98\%). Two studies on Turkish women were also included in this meta-analysis and stated that the prevalence of PMS varied between $32.6 \%$ and $69.9 \%$ (5). The studies that were conducted with university students in our country revealed that the prevalence of PMS varied between $36.4 \%$ and $91.8 \%$ (6-9). University students, who are among the groups that are most affected by PMS, indicated that this period negatively affected their academic achievements, emotional states, social activities, and family relationships (10). Considering the negative effects of PMS on daily life, conducting scientific studies is very important to determine the frequency of PMS and its affecting factors (11). The cause of PMS is unknown; however, hormonal changes are frequently affected by diet, stress, and lifestyle changes (12). Studies examined the status of PMS in some variables, such as the quality of life, lifestyle changes, healthy lifestyle behaviors, smoking, alcohol, and carbohydrate intake (7,13-16). University students have to change their living environments and even cities due to their education, their lifestyles are changed and they encounter many stressful situations. The literature reported no studies on the comfort level of students who stay in dormitories; however, a study indicated that the prevalence of PMS was 4.19 times higher among students who stay in dormitories (17). PMS is considered to change the comfort level by changing the experience of performing activities of daily living with many

\begin{tabular}{|c|c|c|c|c|}
\hline PMSS sub-dimensions & Min & Max & Mean & SD \\
\hline Depressive affection & 7 & 35 & 20.203 & 7.493 \\
\hline Anxiety & 7 & 35 & 14.726 & 6.915 \\
\hline Fatigue & 6 & 30 & 17.124 & 6.599 \\
\hline Nervousness & 5 & 25 & 14.065 & 5.966 \\
\hline Depressive thoughts & 7 & 35 & 16.632 & 8.049 \\
\hline Pain & 3 & 15 & 8.088 & 3.671 \\
\hline Change in appetite & 3 & 15 & 8.576 & 3.710 \\
\hline Sleep change & 3 & 15 & 7.854 & 3.771 \\
\hline Bloating & 3 & 15 & 7.946 & 3.896 \\
\hline Total scale score & 44 & 218 & 115.21 & 41.615 \\
\hline \multicolumn{5}{|l|}{ Comfort scale levels } \\
\hline Relief & 1 & 4 & 2.67 & 0.45 \\
\hline Ease & 1 & 4 & 2.25 & 0.38 \\
\hline Transcendence & 1 & 4 & 2.36 & 0.38 \\
\hline \multicolumn{5}{|l|}{$\begin{array}{l}\text { Comfort scale sub- } \\
\text { dimensions }\end{array}$} \\
\hline Physical & 1 & 4 & 2.39 & 0.41 \\
\hline Psychospiritual & 1 & 4 & 2.39 & 0.38 \\
\hline Sociocultural & 1 & 4 & 2.53 & 0.40 \\
\hline Environmental & 1 & 4 & 2.37 & 0.40 \\
\hline Total scale score & 1 & 4 & 2.43 & 0.35 \\
\hline
\end{tabular}

Min: Minimum, Max: Maximum, SD: Standard deviation, PMSS: Premenstrual syndrome scale, GCS: General comfort scale 
symptoms. Comfort is a concept that an individual feels while performing activities of daily living, including relaxation, peace, and the experience of overcoming the problem (18). Comfort is affected by many biological, psychological, social, and cultural factors, as in PMS. No study on PMS and comfort level was found in the literature. Thus, this study aimed to determine the prevalence of PMS and its associated factors and comfort level in a group of university students who stay in a dormitory.

\section{Research Questions}

What is the prevalence of PMS among students?

What are the factors that affect the occurrence of PMS among students?

Is there a relationship between PMS and general comfort level among students?

\section{Method}

\section{Type and Place of the Study}

This cross-sectional study was conducted in Yozgat Sürmeli Girls' Dormitory, which is located within Yozgat Bozok University Erdoğan Akdağcampus.

\section{Ethical Aspect of the Study}

Approval was obtained from Gazi University Ethics Committee for the Research (no: 2020-162). Permission was obtained from the Provincial Directorate of Youth and Sports and the Directorate of Yozgat Sürmeli Girls' Dormitory for the institution where the study was conducted. The aim of the study was explained to all students who would participate in the study and informed consent was obtained. Permission was obtained from the authors for the scales used in data collection.

\section{Population and Sample of the Study}

This study included 1,162 students staying in Yozgat Sürmeli Girls' Dormitory. Reaching the entire population without sample selection was planned in the study. However, 4 of 1,162 students were foreign nationals who do not speak Turkish and 123 students refused to participate in the study, thus the study was completed with 935 (80\%) students.

\section{Data Collection Tools}

The Participant Information Form prepared by the researchers, the premenstrual syndrome scale (PMSS), and the general comfort scale (GCS) were used as data collection tools in this study.

Participant Information Form: The Participant Information Form, which was prepared following the literature, included the questions that determine the socio-demographic characteristics of females with PMS (age, school, department, grade, place of residence, income status, employment status, characteristics related to height and weight, and history of chronic disease and drug use), lifestyle (smoking, alcohol, and exercise habits), menstruation, and history of PMS (age of menarche, frequency and duration of menstruation, and family history of PMS) $(7,19,20)$. The Participant Information Form consisted of a total of 30 questions.

PMSS: It was developed by Gençdoğan (21) based on the Diagnostic and Statistical Manual of Mental Disorders-III and DSM-IV-R diagnostic criteria in 2006. The Cronbach alpha coefficient of the scale is 0.75 . The scale is a 44 -item 5-point Likert type. While scoring the scale, the "None" option is evaluated as 1 point and the "Continuous" option is evaluated as 5 points. PMSS consists of 9 sub-dimensions. The scale scores range from 44 to 220 points. The theoretical cut-off point is used for the diagnosis of PMS. The presence of PMS is evaluated according to the condition of exceeding $50 \%$ of the score obtained from each sub-dimension of the scale. The Cronbach alpha coefficient of the scale is 0.75 (21). This study revealed that the Cronbach alpha coefficient of the scale was 0.97 . Written permission was obtained from Gençdoğan (21) to use PMSS in this study.

GCS: The Turkish validity and reliability study of the GCS, which was developed by Katharina Kolcaba in 1992, was performed by Kuğuoğlu and Karabacak (22). The scale is 4-point Likert type consists of a total of 48 items. The comfort levels of the scale are a relief (16 items), ease (17 items), and transcendence (15 items). The scale consists of positive and negative items in the mixed form. The reverse-coded items in the scale evaluation are presented in the table below. The highest and lowest scores that are obtained from the scale are 192 and 48, respectively. The scale is determined with a value between 1 and 4 by dividing the total score by the number of items. The comfort level increases as the scale score approach 4 . The Cronbach alpha coefficient of the scale was found to be 0.85 in the validity and reliability study (22). This study revealed that the Cronbach alpha coefficient of the scale was 0.88 . Written permission was obtained from Kuğuoğlu and Karabacak (22) to use GCS in this study.

\section{Statistical Analysis}

Statistical Package for the Social Sciences 21.0 (SPPS-PC Version 21.0) package program was used for the statistical analysis of the data. Number, percentage, arithmetic mean, t-test, chi-square, logistic regression, and correlation analysis were used for data evaluation.

\section{Results}

The mean age of the students who participated in the study was 20.81 years. Students who study daytime education accounted for $76.8 \%$ and $46.5 \%$ were 3 rd-grade students. Additionally, $78.8 \%$ of students had a nuclear family structure, and mothers of $54.4 \%$ and fathers of $36.8 \%$ were primary school graduates. Moreover, $54.2 \%$ indicated that their income was less than their expenses.

Chronic disease was determined in $11.9 \%$ of students, thus use drugs, whereas $18.4 \%$ experienced polycystic ovarian syndrome symptoms and $4.3 \%$ have obesity.

Students who added salt without tasting the food account for $73.5 \%$ and $31.3 \%$ had the habit of consuming coffee daily. Of 
those who consumed coffee, $54.3 \%$ consumed 2 cups or more of coffee daily. Smokers accounted for $13 \%$ of students and $4.3 \%$ consumed alcohol. Of the smoker students, $45.1 \%$ had been smoking for 4 years or more and $41.8 \%$ smoked 6 cigarettes or more a day. Of the students, 9.1\% had regular exercise, of whom $52.9 \%$ regularly exercised $1-3$ times a week and only $32.9 \%$ had exercise duration of $31 \mathrm{~min}$ or more.

The history of first menstruation of $54.8 \%$ of students was at the age of 13 years and younger, $77.8 \%$ had dysmenorrhea, and $26.2 \%$ used any method, such as painkiller and hot application, to cope with dysmenorrhea. Dysmenorrhea was determined in $57.2 \%$ of students in one or more of their mothers and sisters and $49.2 \%$ of these people had the symptoms of PMS.

The total score of the PMSS was $115.21 \pm 41.615$, wherein the highest score is $20.203 \pm 7.493$ from the depressive affection dimension and the lowest score is $7.854 \pm 3.771$ from the sleep change dimension.

The total score of the GCS was $2.43 \pm 0.35$. The highest value of the sub-dimensions of the comfort scale is $2.53 \pm 0.40$ in the sociocultural dimension. The highest value among the levels of the scale was found at the relief level by $2.67 \pm 0.45$.

PMS by the scoring of 132 points and above was determined in $34.2 \%$ of students.

A weak and negative relationship was found between the PMSS and the GCS.

The examination of the comfort levels according to the presence of PMS revealed lower comfort scores in students with PMS. A statistical significance was found at the relief and transcendence levels of the scale compared to those with and without PMS $(\mathrm{p}<0.01)$. Physical, sociocultural, and environmental dimensions of the scale were statistically significant compared to students with and without PMS $(\mathrm{p}<0.01)$.

A statistically significant relationship was found between PMS and the age of menarche, chronic disease, presence of polycystic ovarian syndrome symptoms, drug use, use of salt without tasting the food, daily coffee consumption, smoking, having dysmenorrhea, using dysmenorrhea coping methods, and dysmenorrhea and PMS in first-degree relatives $(\mathrm{p}<0.05)$.

The risk of PMS was higher in students with menarche at age 13 years or younger ( 1.366 times, $\mathrm{p}=0.036$ ), who had the chronic disease (2,512 times, $\mathrm{p}=0.001)$, a high salt use ( 1.626 times, $\mathrm{p}=0.003)$, a high daily coffee consumption (1,882 times, $\mathrm{p}=0.000)$, had dysmenorrhea (2,026 times, $\mathrm{p}=0.000)$, and used any method to cope with dysmenorrhea (1,614 times, $\mathrm{p}=0.003)$.

\section{Discussion}

This study aimed to determine the prevalence of PMS and its associated factors and comfort level in a group of students who stay in a dormitory and revealed that $34 \%$ of students had PMS. The study of Güvenç et al. revealed that the prevalence of PMS was $36 \%$, which is similar to our study results. The prevalence of
PMS was 62\% in the study of Bakır and Yangın (7) and 57\% in the study of Kisa et al. (19) The prevalence of PMS was $60 \%$ in the study of Silva et al. (23) and $84 \%$ in the study of Houston et al. (24). A wide range of results was obtained in studies on the prevalence of PMS. Many factors, such as the presence of different evaluation criteria, different attitudes of different cultures, and different forms of health service delivery, can make the determination of the true prevalence difficult. Additionally, the same scale is used in the studies conducted in our country; however, calculations according to different cut-off points led to different results in PMS prevalence. Our study used 132 as the cut-off value of the scale, and the prevalence of PMS was found to be $34.2 \%$.

Our study revealed that the total score of PMSS was 115.21 \pm 41.615 . The highest score on the scale was in the depressive affection dimension and the lowest was in the sleep change dimension. The study by Topatan and Kahraman (16) with university students revealed that the total score of the PMSS was $118.4 \pm 32.4$. Similarly, the highest score was obtained from the depressive affection dimension (18.21 \pm 7.42$)$ and the lowest score from the sleep change dimension $(7.85 \pm 2.96)(16)$. Another study revealed that the mean total score from the PMSS was $122.14 \pm 32.60$ (25). This study revealed that the highest score was from the depressive thought sub-dimension $(20.42 \pm 6.76)$ and the lowest score was from the pain sub-dimension $(8.10 \pm 3.27)$. The study results of Tanriverdi et al. (26) are also similar to the study of Aba et al. (25) and differ from the results of this study.

The study revealed a statistically significant relationship between the menarche age of the students and the PMSS and observed that the risk of PMS was $1,366(\mathrm{p}=0.036)$ times higher in students whose menarche age was 13 years and younger. The literature reported studies that revealed the relationship between PMS and menarche age as statistically insignificant $(4,14,25,27)$.

No statistically significant relationship was found between the body mass index and PMS in the literature $(4,25,28)$. The results on body mass index in this study are also consistent with the literature.

PMS coexists with dysmenorrhea in many women, and premenstrual symptoms alternate with dysmenorrhea at the beginning of menstruation $(7,14,25,29)$. Our study revealed that $77.8 \%$ of the students had dysmenorrhea and that the risk of PMS was 2.026 times higher in students with dysmenorrhea. The study conducted by Bakır and Yangın revealed this value to be 1.62. The study on Japanese students that was conducted by Yamamoto et al. (30) revealed a relationship between dysmenorrhea and PMS. Studies also reported different results from our study. The study that was conducted by Rupani and Lema (31) and Freeman et al. (32) revealed no relationship between dysmenorrhea and PMS.

Our study revealed that the risk of PMS was 1.882 times higher in students who consumed coffee daily. Several studies that were conducted with university students revealed that the chi-square analysis of coffee consumption was statistically significant; 
Table 2. Prevalence of PMS

\begin{tabular}{l|l|l|}
\hline & Number & Percentage (\%) \\
\hline $\begin{array}{l}\text { Those with premenstrual } \\
\text { syndrome }\end{array}$ & 320 & 34.2 \\
$\begin{array}{l}\text { Those without premenstrual } \\
\text { syndrome }\end{array}$ & 615 & 65.8 \\
\hline $\begin{array}{l}\text { Total } \\
\text { PMS: Premenstrual syndrome }\end{array}$ & 935 & 100 \\
\hline
\end{tabular}

Table 3. Correlation of the PMS scale and the GCS

\begin{tabular}{l|l}
\hline Scale & Comfort scale \\
\hline Having PMS & $\mathrm{rP}$ \\
\hline PMS. Premenstrual syndrome, GCS. General comfort scal & -0.1920 .001 \\
\hline
\end{tabular}

Table 4. Evaluation of the presence of PMS and comfort levels in students

\begin{tabular}{|l|l|l|l|l|}
\hline Comfort levels & PMS $<132$ & PMS $\geq 132$ & t-test* & $p$ \\
\hline Relief & $2.757 \pm 0.466$ & $2.526 \pm 0.376$ & 8.194 & $\mathbf{0 . 0 0 0}$ \\
\hline Ease & $2.254 \pm 0.400$ & $2.260 \pm 0.339$ & -0.249 & 0.803 \\
\hline $\begin{array}{l}\text { Transcendence } \\
\text { Comfort sub- } \\
\text { dimensions }\end{array}$ & $2.387 \pm 0.414$ & $2.317 \pm 0.327$ & 2.792 & $\mathbf{0 . 0 0 5}$ \\
\hline $\begin{array}{l}\text { Physical } \\
\text { Psychospiritual }\end{array}$ & $2.400 \pm 0.400$ & $2.382 \pm 0.346$ & 0.680 & 0.497 \\
\hline $\begin{array}{l}\text { Sociocultural } \\
\text { Environmental }\end{array}$ & $2.567 \pm 0.429$ & $2.482 \pm 0.358$ & 3.232 & $\mathbf{0 . 0 0 1}$ \\
\hline $\begin{array}{l}\text { GCS total score } \\
\text { Gcs }\end{array}$ & $2.405 \pm 0.418$ & $2.327 \pm 0.385$ & 2.795 & $\mathbf{0 . 0 0 5}$ \\
\hline *Independent sample t-test, PMS: Premenstrual syndrome & & \\
\hline
\end{tabular}

however, the presence of PMS in the logistic regression analysis was not statistically significant $(7,14)$. A study conducted with university students in Thailand revealed a relationship between coffee consumption and PMS symptoms (33). The study conducted by Moon-Soo et al. (34) with university students in Korea revealed a statistically significant difference in coffee consumption between the group with moderate to severe PMS and the group with mild PMS. Another study revealed no statistically significant relationship between the consumption of tea, coffee, and cola-containing caffeine and the PMS $(13,15)$. The study conducted by Çelik et al. (35) revealed no significant relationship with coffee consumption, whereas a statistically significant relationship between cola and tea-drinking variables. A study on high-caffeine coffee intake conducted with nurses revealed no significant relationship between PMS and caffeine intake (36).

The literature reported many studies on the presence of PMS in smoking and alcohol use. A study conducted with Japanese adolescent students revealed that smoking and alcohol use increased problems, such as concentration disorders, behavioral changes, fluid retention, and negative affection, in the premenstrual period (37). Studies revealed statistically significant results in the chi-square tests on alcohol, smoking, and PMS $(14,15,38)$. The study of Pinar et al. (14) revealed that the risk of PMS was 0.4 times higher in smoker students compared to non-smokers. Studies by Demir et al. (13) and Çelik et al. (35) revealed a statistically significant relationship between smoking and PMS. Deuster et al. (39) also revealed that the prevalence of PMS was higher in those who smoked for $>5$ years. The study on PMS that was conducted by Bakır and Yangın (7) revealed no association with smoking, whereas results of the chi-square analysis of alcohol use were significant and regression results were statistically insignificant. Our study revealed no relationship between alcohol use and the presence of PMS; however, a relationship was found with smoking. A recent case-control study on smoking and PMS determined that smoking and PMS are correlated (40).

The literature reported studies that reveal the relationship of PMS with genetic factors $(7,13-15)$. The square test in our study revealed the presence of PMS and dysmenorrhea in the mother, elder sister, or younger sister, which was statistically significant. A study in Malaysia determined that PMS was more common in people with any relative complaints of PMS (4). A study conducted in Turkey revealed that PMS was highly detected in people with PMS complaints in their mothers or sisters (13). The study of Bakır and Yangın determined that the risk of PMS was 2.27 times higher in students whose mothers had PMS complaints. Another study found that the presence of PMS in mothers of students increased the risk of PMS by 1.68 times (8).

Another PMS symptom is edema. Salt intake increases the formation of edema in the body (41). Our study revealed that $26.5 \%$ of students used salt without tasting the food. Our analysis on the risk of PMS was 1.626 times higher in students who used salt without tasting the food. The study of Asscr et al. (8) revealed that $35.6 \%$ of students used salt without tasting the food, and the PMSS score was found significantly $(\mathrm{p}=0.021)$ higher in students who used salt. The study conducted by Hashim et al. (28) found that the use of salt increased the risk of PMS. Şahin et al. (20) revealed that the risk of PMS was 1,982 times higher in students who used salt, whereas Bakır and Yangin (7) found this value as 2,415 . The study conducted by Pinar et al. (14) determined that salt was not a factor that increased the risk of PMS.

Exercise is also used to relieve PMS by increasing serotonin levels $(25,41)$. Şahin et al. (20) revealed that the risk of PMS was 1.710 times higher in those who did not exercise. Our study revealed no significant relationship between exercise and PMS prevalence. The literature reported similar results $(8,13,25)$. A low number of students, who exercised regularly in the studies with similar results to our study, and this study, may have caused the statistics to be insignificant. 
Table 5. Examination of the factors affecting the presence of PMS among students

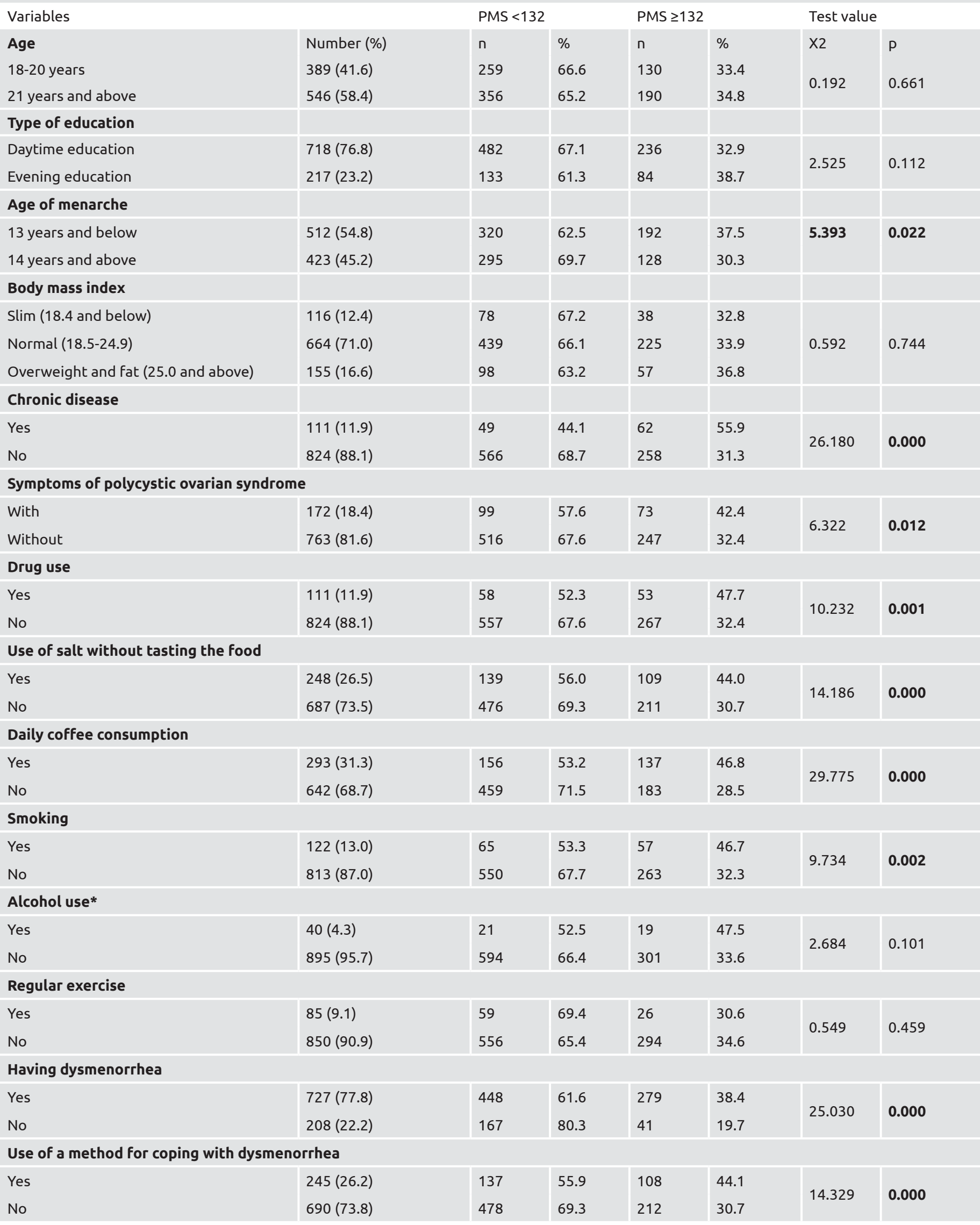


Table 5. Continued

Variables

PMS $<132$

PMS $\geq 132$

Test value

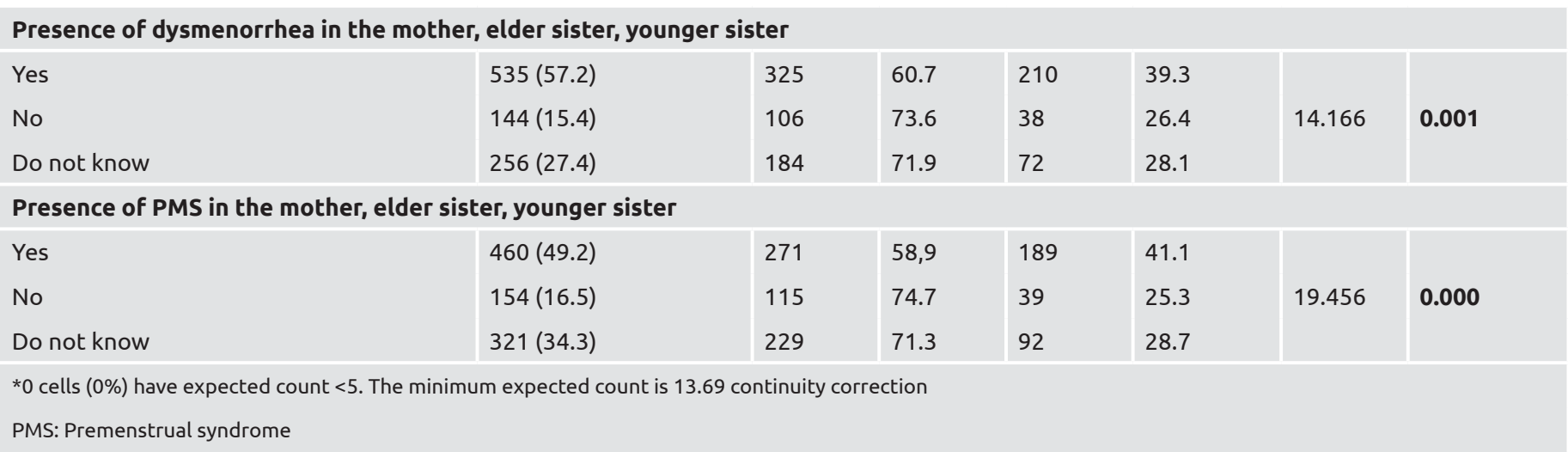

Our study revealed that $18.4 \%$ of students had polycystic ovarian syndrome symptoms. A statistical significance was found between having the symptoms of the polycystic ovarian syndrome and PMSS scores. The fluctuation in hormonal levels in polycystic ovarian syndrome and PMS causes the exacerbation of PMS syndromes and the emergence of short-term mixed mood changes (42). Our study revealed that the risk of PMS was 2,512 times higher in people with any chronic disease compared to those without chronic disease. The study conducted by Arslantaş et al. (15) revealed a statistically significant difference between those with and without chronic diseases other than gynecological diseases and the presence of PMS was. The study conducted by Acikgoz et al. (38) revealed that PMS was 2.35 times higher in students with chronic diseases. Our study results were consistent with the literature. Our study revealed a statistical significance between regular drug use for chronic diseases and PMSS score, whereas no statistically significant difference in the regression analysis.

\section{Study Limitations}

Our study revealed a weak and negative relationship between GCS and PMSS. The mean scores in each level and dimension of the GCS were lower in students with PMS. The relief and ease levels in the GCS were significantly lower in people with PMS. The scores of the students with PMS in the physical, sociocultural, and environmental dimensions of the scale subdimensions were significantly lower. No study on the relationship between comfort level and PMS was reported in the literature; however, it can be said that PMS negatively affects the comfort level of students.

\section{Conclusion}

Of the university students who participated in the study, $34.2 \%$ had PMS. The total score of the GCS of the students was $2.43 \pm 0.35$, and based on the scores from the subscales and levels of GCS, the comfort levels of students with PMS were found to be lower. Considering our study results, menarche age under 13 years, presence of chronic disease, dysmenorrhea, salt use, and coffee consumption increased the risk of PMS. Many factors lead to the occurrence of PMS. Interventional studies are necessary to reduce the risk factors for PMS that significantly affect the women's health or the effects of these risk factors.

Table 6. Logistic regression analysis of the factors that affect the presence of premenstrual syndrome in students

\begin{tabular}{|c|c|c|c|c|c|c|c|}
\hline \multirow{2}{*}{ Variables } & \multirow{2}{*}{ ß } & \multirow{2}{*}{$\mathrm{SH}$} & \multirow{2}{*}{ Wald } & \multirow{2}{*}{$P$} & \multirow{2}{*}{ OR } & \multicolumn{2}{|c|}{$95 \% \mathrm{Cl}$ for EXP (B) } \\
\hline & & & & & & Lower & Upper \\
\hline Constant & -2.109 & 0.212 & 99.244 & 0.000 & 0.121 & & \\
\hline Have a chronic disease (1) & 0.921 & 0.273 & 11.360 & 0.001 & 2.512 & 1.470 & 4.292 \\
\hline Polycystic ovarian syndrome (1) & 0.313 & 0.185 & 2.868 & 0.090 & 1.367 & 0.952 & 1.963 \\
\hline Use of salt (1) & 0.486 & 0.162 & 8.988 & 0.003 & 1.626 & 1.183 & 2.233 \\
\hline Coffee consumption (1) & 0.632 & 0.157 & 16.210 & 0.000 & 1.882 & 1.383 & 2.560 \\
\hline Smoking (1) & 0.346 & 0.213 & 2.645 & 0.104 & 1.413 & 0.932 & 2.143 \\
\hline Dysmenorrhea (1) & 0.706 & 0.200 & 12.518 & 0.000 & 2.026 & 1.370 & 2.995 \\
\hline Coping with dysmenorrhea (1) & 0.479 & 0.163 & 8.637 & 0.003 & 1.614 & 1.173 & 2.222 \\
\hline
\end{tabular}




\section{Ethics}

Ethics Committee Approval: Approval was obtained from Gazi University Ethics Committee for the Research (no: 2020-162). Permission was obtained from the Provincial Directorate of Youth and Sports and the Directorate of Yozgat Sürmeli Girls' Dormitory for the institution where the study was conducted.

Informed Consent: The aim of the study was explained to all students who would participate in the study and informed consent was obtained.

Peer-review: Externally peer reviewed.

\section{Authorship Contributions}

Surgical and Medical Practices: D.Y.G., Concept: D.Y.G., N.B., Design: D.Y.G., N.B., Data Collection or Processing: D.Y.G., Analysis or Interpretation: D.Y.G., N.B., Literature Search: D.Y.G., N.B., Writing: D.Y.G., N.B.

Conflict of Interest: No conflict of interest was declared by the authors.

Financial Disclosure: The authors declared that this study received no financial support.

\section{References}

1. Zaka M, Mahmood KT. Pre-menstrual syndrome-a review. J Pharm Sci Res 2012;4:1684-91.

2. Abeje A, Berhanu Z. Premenstrual syndrome and factors associated with it among secondary and preparatory school students in Debremarkos town, North-west Ethiopia, 2016. BMC Res Notes 2019;12:535.

3. Gamal AM, Shahin MA. Premenstrual Syndrome, associated symptoms and evidence-based nursing management: A comparative study between rural menoufia governorate (Egypt) and hodidha governorate (Yemen). Am J Nurs Sci 2015;4:84-93.

4. Molugulu N, Tumkur A, Nilugal KC. Study of premenstrual syndrome among future healthcare professionals in masterskill global college. IJSR 2016;8:66-71.

5. Direkvand-Moghadam A, Sayehmiri K, Delpisheh A, Kaikhavandi S. Epidemiology of Premenstrual Syndrome (PMS)-A systematic review and meta-analysis study. Journal of clinical and diagnostic research. JCDR 2014;8:106-9.

6. Guvenc G, Kilic A, Akyuz A, Ustunsoz A. Premenstrual syndrome and attitudes toward menstruation in a sample of nursing students. J Psychosom Obstet Gynecol 2012;33:106-11.

7. Bakır N, Yangın HB. The relationship between premenstrual syndrome and healthy lifestyle among university students. Life Skills Journal of Psychology 2012;3:39-51.

8. Aşcı Ö, Süt HK, Gökdemir F. Prevalence of Premenstrual Syndrome Among University Students and Risk Factors. DEUHFED 2016;9:79-87.

9. Goker A, Artunc-Ulkumen B, Aktenk F, İkiz N. Premenstrual syndrome in Turkish medical students and their quality of life. J Obstet Gynaecol 2015;35:275-8.
10. Eke AC, Akabuike JC, Maduekwe K. Predictors of premenstrual syndrome among Nigerian university students. Int J Gynecol Obstet 2011;112:63-4.

11. Öncel S, Pınar A. Premenstrual sendromda tanı, tedavi ve hemşirelik yaklaşımı. Sendrom (Hemşirelik) 2006;18:86-91.

12. Mahesh A, Tirmizi SZA, Sanwer Ali S. Frequency and associated factors of premenstrual syndrome in medical college girls. Medical Channel 2011;17:34-8.

13. Demir B, Yıldız AL, Güvendağ GES. Analysis of premenstrual syndrome incidence in medical staff and factors affecting premenstrual syndrome incidence. J Turkish Gynaecol Obstet Found 2006;3:262-70.

14. Pinar G, Colak M, Oksuz E. Premenstrual Syndrome in Turkish college students and its effects on life quality. Sex Reprod Healthc 2011;2:21-7.

15. Arslantaş H, Abacigil F, Çinakli Ş. Relationship between premenstrual syndrome and basic personality traits: a cross-sectional study. Sao Paulo Med J 2018;136:339-45.

16. Topatan S, Kahraman Ş. The methods they applied for coping and the quality of life of university students living the premenstrual syndrome. J Anatolia Nurs Health Sci 2020;23:35-44.

17. Selçuk Tari K, Avci D, Alp Yilmaz F. The Prevalence of Premenstrual Syndrome Among Nursing Students and Affecting Factors. J Psychiatric Nursing 2014:98-103.

18. Yücel ŞÇ. Kolcaba's comfort theory. Ege Universitesi Hemşirelik Fakültesi 2011;27:79-88.

19. Kısa S, Zeyneloğlu S, Güler N. Prevalence of premenstrual syndrome among university students and affecting factors. Gümüşhane University Journal of Health Sciences 2012;1:284-97.

20. Şahin S, Ozdemir K, Unsal A. Evaluation of premenstrual syndrome and quality of life in university students. J Pak Med Assoc 2014;64:915-22.

21. Gençdoğan B. A new scale for premenstrual syndrome. Psychiatry in Turkey 2006;8:81-7.

22. Kuğuoğlu S, Karabacak Ü. Turkish version of the general comfort questionaire. Florence Nightingale J Nurs 2008;16:16-23.

23. Silva CMLD, Gigante DP, Carret MLV, Fassa AG. Population study of premenstrual syndrome. Rev Saude Publica 2006;40:47-56.

24. Houston AM, Abraham A, Huang Z, D’Angelo LJ. Knowledge, attitudes, and consequences of menstrual health in urban adolescent females. J Pediatr and Adolesc Gynecol 2006;19:271-5.

25. Aba YA, Ataman H, Dişsiz M, Sevimli S. Premenstrual Syndrome, physical activity and quality of life in young women. JAREN 2018;4:75-82.

26. Tanrıverdi G, Selçuk E, Okanlı A. Prevelance of premenstrual syndrome in university students. Anatolian Journal of Nursing and Health Sciences 2010;13:52-7.

27. Tolossa FW, Bekele ML. Prevalence, impacts and medical managements of premenstrual syndrome among female students: cross-sectional study in college of health sciences, Mekelle University, Mekelle, Northern Ethiopia. BMC Women's Health 2014;14:52. 
28. Hashim MS, Obaideen AA, Jahrami HA, Radwan H, Hamad HJ, Owais AA, et al. Premenstrual syndrome is associated with dietary and lifestyle behaviors among university students: A cross-sectional study from Sharjah, UAE. Nutrients 2019;11:1939.

29. Ölçer Z, Bakır N, Aslan E. Effect of university students' personality on premenstrual complaints. Journal of Duzce University Health Sciences Institute 2017;1:30-7.

30. Yamamoto K, Okazaki A, Sakamoto Y, Funatsu M. The relationship between premenstrual symptoms, menstrual pain, irregular menstrual cycles, and psychosocial stress among Japanese college students. J Physiol Anthropol 2009;28:129-36.

31. Rupani N, Lema VM. Premenstrual tension among nurses in Nairobi, Kenya. East Afr Med J 1993;70:310-3.

32. Freeman E, Rickels K, Sondheimer S. Premenstrual symptoms and dysmenorrhea in relation to emotional distress factors in adolescents. J Psychosom Obstet Gynecol 1993;14:41-50.

33. Thu M, Diaz E, Kapaw S. Premenstrual syndrome among female university students in Thailand. AU JT 2006;9:158-62.

34. Moon-Soo Lee MD, Jaewon Yang MD, Young-Hoon Ko MD, Seung-Duk Ko, Sook-Haeng Joe MD. Characteristics of PMS and PMDD in female college students. Korean Journal of Psychosomatic Medicine 2012;20:22-31.

35. Çelik MY, Polat Y, Yıldırım AD. Premenstrual syndrome prevelance in students and comparison of life satisfaction scale scores and premenstrual syndrome scale scores of students. Health and Society 2019;29:50-7.
36. Purdue-Smithe AC, Manson JE, Hankinson SE, Bertone-Johnson ER. A prospective study of caffeine and coffee intake and premenstrual syndrome. Am J Clin Nutr 2016;104:499-507.

37. Hirokawa K. Premenstrual symptoms in young japanese women: Agency, communion and lifestyle habits. Sex Roles 2011;65:56-68.

38. Acikgoz A, Dayi A, Binbay T. Prevalence of premenstrual syndrome and its relationship to depressive symptoms in first-year university students. Saudi Med J 2017;38:1125.

39. Deuster PA, Adera T, South-Paul J. Biological, social, and behavioral factors associated with premenstrual syndrome. Arch Fam Med 1999;8:122-8.

40. Fernández MDM, Montes-Martínez A, Piñeiro-Lamas M, RegueiraMéndez C, Takkouche B. Tobacco consumption and premenstrual syndrome: A case-control study. PloS One 2019;14:e0218794.

41. Abay H, Kaplan S. Current approaches in premenstrual syndrome management. Bezmialem Science 2019;7:150-6.

42. Jalnapurkar I, Findley JC. A case of repeated mixed mood episodes with psychotic symptoms associated with the premenstrual period in a patient with polycystic ovarian syndrome. Gynecol Endocrinol 2018;34:467-9. 